\title{
Interreligous Marriage According to Indonesian Legislation
}

\author{
Kadriah Kadriah ${ }^{1, *}$ Teuku Saiful ${ }^{1}$ Muhammad Naufal Hidayat ${ }^{2}$ \\ ${ }^{1}$ Law Faculty, Syiah Kuala University, Banda Aceh, Indonesia \\ ${ }^{2}$ Ar Raniry Islamic University, Banda Aceh, Indonesia \\ *Corresponding author. Email: kadriah@unsyiah.ac.id
}

\begin{abstract}
Article 2 paragraph (1) of Law No. 1 of 1974 states that marriage is valid if it is performed according to each religion and belief. Article 2 paragraph (2) continues that every marriage must be registered. The recorded marriage is a legal marriage as regulated in Article 2 paragraph (1). Thus, in Indonesia, there is no known interfaith marriage. In society, interfaith marriages continue to occur. The purpose of this paper is to explain interfaith marriage from a legal perspective in Indonesia and what couples who perform interfaith marriages do in relation to the implementation of their marriage. This research is normative juridical research. The data used in this research is secondary data (literature). Literature research is carried out by studying various literature, analysing various laws and regulations relating to marriage as well as several judges' decisions regarding interfaith marriages. The results showed that the Marriage Law did not provide opportunities for interfaith marriages. To overcome the legal vacuum of Law No. 23 of 2006 as amended by Law No. 24 of 2013 concerning Amendments to Law No. 23 concerning Population Administration, it provides opportunities for couples who are going to have interfaith marriages to register their marriages.
\end{abstract}

Keywords: Marriage, Different Religions, Legislation.

\section{INTRODUCTION}

Humans are social creatures that are interdependent with one another in meeting their daily needs. One of the necessities of human life is the nature or desire to continue the offspring, which can be carried out by establishing a marriage between a woman and a man who has met the requirements for marriage. Marriage is a sunnatullâh that applies in general and the behavior of God's creatures, so that with marriage, life in this world can develop to enliven this vast nature from generation to generation. Marriage is an instinctual requirement that applies to all of His creatures, be it humans, animals, or plants.

Humans are intelligent creatures; therefore, marriage is a culture for offspring in order to continue and obtain a calm, orderly life and follow the development of human culture. In a simple society, the culture of marriage is in a simple, narrow and even closed form, whereas in modern society the culture of marriage is more open.[1] Marriage is inseparable from the influence of the culture and environment in which the community is located. Marriage (commonly known as marriage), is a method chosen by God to maintain human life on earth with the aim of maintaining the honor and dignity of humankind.

The Marriage Law in Indonesia not only defines marriage as a civil bond, but marriage is also seen as a physical and spiritual bond based on an agreement between a man and a woman to build a happy and eternal family based on values. the value of the One and Only Godhead. Provisions regarding the legality of marriage refer to Article 2 of the Marriage Law which states that a marriage is valid if it meets the following requirements: (1) it is carried out according to the law of each religion and belief, (2) the marriage must be recorded according to statutory regulations.[2] From the explanation of Article 2 paragraph (1), it is implied that marriage must be carried out by a partner of the same religion. This is understandable considering that every religion has legal conditions for marriage that are different from other religions. 
Article 2 paragraph (2) continues that every marriage must be registered. Recording will be carried out when the requirements according to the religion and belief of the prospective bride have been met.[3] The provisions regarding registration are more specifically regulated in Article 2 of Government Regulation Number 9 of 1975 which states that for couples who are Muslim, registration is carried out by registrar employees as referred to in Law Number 32 of 1954 concerning registration of marriage, divorce, and reconciliation. Meanwhile, the registration of marriages carried out by people of religions other than Islam then the registration will be carried out by the marriage registrar employee at the Civil Registry Office. Article 9 of the government regulation stipulates that the registration officer will announce the marriage plan containing the religion or belief of the prospective bride. From the explanation above, it is implied that the Marriage Law in Indonesia does not recognize interfaith marriage. Government Regulation Number 9 of 1975 does not regulate the registration of marriages in the prospective that the bride and the groom have a different religion. This makes interfaith marriage relatively difficult in Indonesia[4] The Indonesian Ulema Council once issued a fatwa that interfaith marriages are haram in Indonesia. Even so, interfaith marriages still occur in society even though the numbers do not always show an increase.

\section{RESEARCH METHODS}

This research is a normative juridical research. The data used in this research is a secondary data (literature). Literature research is carried out by studying a variety of literature, both printed media in the form of books, laws, and regulations, journals, judges' decisions on interfaith marriages and electronic media, all of which are used as material for analysis so that a legal formula is found on interfaith marriage in Indonesia.

\section{FINDINGS AND DISCUSSION}

Based on the background above, the problems that are interesting to study in this paper are, as follows:

1. How is interfaith marriage in the view of law in Indonesia?

2. What are done by couples who have interfaith marriages in relation to the implementation of their marriage?

\subsection{Marriage with different religions in the view of law in Indonesia}

In western countries, especially interfaith marriages are not an issue that must be discussed. This is different from the conditions that occur in Indonesia. Even though Indonesia is not a religious country, Indonesia is a country that highly values religious values. Pancasila, which is the basis of the Indonesian state in the first precept, directly regulates the one and only Godhead, which means the recognition of the Indonesian nation for divine values that must be carried out by every Indonesian citizen. This statement of divine values is not only found in the first principle of Pancasila but can also be found in the preamble of the 1945 Constitution of the third paragraph which reads "By the grace of Allah the Almighty ...". Furthermore, in the 1945 constitution in Article 29 it is again stated in paragraph (1) that the State is based on the One Godhead.

Article 2 paragraph (1) of the Marriage Law states that a marriage is valid if it is carried out according to the respective religious and belief laws. This explains that there is no marriage outside the law of each religion and belief. The state only recognizes the legality of a marriage if it is carried out according to the religious law of each partner. Thus a marriage is valid if the conditions and harmony of the marriage are fulfilled according to each religion or belief. Article 2 wants to make clear that Indonesia does not recognize interfaith marriage. A judicial review of the existence of Article 2 paragraph (1) of the Marriage Law was submitted to the Constitutional Court in 2014. The Petitioner feels that Article 2 is against human rights where everyone is free to practice or not practice their religion. Applicants for judicial review of the Marriage Law, Damian Agata Yuvens, questioned why the state cannot facilitate interfaith marriage. In fact, the state accommodates divorce which is also prohibited according to the teachings of one religion[5] The petitioners wish that the provisions regarding the interpretation of the validity of marriage are not interpreted unilaterally by the state, but left to individuals. The examiners of the Marriage Law material want the interpretation of Article 2 Paragraph 1 to be changed to "Marriage is valid if it is carried out according to the law of each of their respective religions and beliefs, as long as the interpretation of the law of religion and belief is submitted to the prospective of the bride and groom". According to the applicant for norms in Article 2 paragraph 1 of the Marriage Law, it opens 
up space for interpretation and restrictions so that it cannot guarantee the fulfillment of the right to a legal certainty that is just and contrary to the provisions of freedom as mandated by the 1945 Constitution. The Constitutional Court Judge on June 182015 finally declared that the petition was rejected. The judge considered that the arguments presented by the applicant were groundless[6]

According to the Court, the divine principle mandated in the 1945 Constitution is a manifestation of religious recognition as a country based on the one and only Godhead, actions or actions taken by citizens have a close relationship with religion, and one of them is marriage. The Constitutional Court is of the opinion that in terms of exercising their rights and freedoms, every citizen is obliged to comply with the restrictions stipulated by law. This is to ensure recognition and respect for the rights and freedoms of others, as well as to fulfill fair demands in accordance with moral considerations, religious values, security, and public order in a democratic society. Marriage is one of the problem areas regulated in the law in Indonesia. For this reason, all actions and actions taken by citizens, including those related to marriage matters, must be obedient and not in conflict with or violate statutory regulations. The Constitutional Court also views that the state has a role to provide protection for citizens to form families and continue their offspring through legal marriage, which is a form and guarantee of human survival. Marriage should not only be seen from the formal aspect, but also other aspects such as spiritual and social aspects. The Constitutional Court stipulates that the provisions concerning the legality of marriage are determined by religion, while the state determines the validity administratively through statutory provisions. Marriage has a close relationship with religion and spirituality, considering that the marriage law views marriage as a physical and spiritual relationship between a woman and a man with the intention of running a happy and eternal family based on One God. Therefore, marriage is a sacred event in the life of every human being because its implementation is actually done because of God's commandment and each couple asks God to be given peace and happiness in navigating the household ark.

Even though we are talking about constitutional rights, this does not mean that these constitutional rights can be exercised freely. A limitation is needed precisely in order to respect the constitutional rights of others. Thus, the provisions of Article 2 paragraph 1 of the Marriage Law are in line with Article $28 \mathrm{~J}$ of the 1945 Constitution which states "Everyone has the right to respect the human rights of others in an orderly life in society, as a nation and as a state". In exercising the right to freedom, everyone is obliged to comply with the restrictions stipulated by law for the sole purpose of guaranteeing recognition and respect for the rights and freedoms of others and to fulfill fair demands in accordance with moral considerations and values. religion, security, and public order in a democratic society. If the judicial review of Article 2 paragraph (1) of the Marriage Law is accepted, it is feared that there will be disharmony in the life of the nation and state, considering that almost all religions do not justify interfaith marriage.

Minister of Religion Lukman Hakim gave the view that the Constitutional Court's decision was in accordance with the identity of the religious Indonesian people who uphold religious values as reflected in the Pancasila and the 1945 Constitution. The Constitutional Court decision reflects Indonesian values. which of course is different from the values prevailing in other countries.[7] According to the Minister of Religion, marriage is a sacred thing and even is a form of worship in every religion. When religions claim not to recognize interfaith marriage, the state has guaranteed everyone to practice their religion. The prohibition of interfaith marriages is actually not only contained in Article 2 (paragraph) 1 of the Marriage Law but can also be found in Article 8 letter (f) of the Marriage Law which regulates "Marriage is prohibited between two people who have a relationship that is prohibited by their religion or other regulations that are prohibited, prohibited from getting married. Islam is strictly an interfaith marriage. Article 40 letter (c) of the Compilation of Islamic Law (KHI) states that "it is prohibited to have a marriage between a man and a woman who is not a Muslim. Of all the articles of the regulations that were tried to be lifted, all directed that marriage according to their respective religions did not explicitly mention the prohibition of interfaith marriage. Quraisysh Shihab firmly stated that interfaith marriages are not valid either according to religion or according to state.[8]

Interfaith marriages will have a psychological and juridical impact on both; husband and wife and the children born in the marriage. The psychological impact can even be experienced by families or relatives considering that interfaith marriages are considered taboo in religious Indonesian society. There is even an assumption that interfaith marriage 
is the same as adultery and that the child born is not a legal child.[9]

The state declares the validity of a marriage if it is carried out according to the respective religious laws. Therefore, if all the provisions regarding the legal conditions of marriage according to religious law have been fulfilled, the state views the marriage as valid and vice versa.

Different religions can lead to domestic strife. Likewise, children born in interfaith marriages will be psychologically disturbed by the religious differences of their parents. Both parents try to convince the child of their religion. Such conditions should not occur considering the child is experiencing a period of personality formation and development where religious values play a very important role in the child's development. Leaving children without religious instruction is a big mistake. Confusion will be experienced by a child to determine which religion he/she wants to take[10]

A child may choose not to have a religion, which leads to atheism. This experience has been experienced by Tirta Mandira Hudi or better known as dr. Tirta. He was born to a different religious partner. From elementary school to high school he chose to be an atheist, and at the age of twentythree he chose to convert to Islam.[11] This condition becomes a pressure for children to follow the religion of their mother or father.

The juridical impact is related to the validity of marriage. This is because Article 2 paragraph (1) of the Marriage Law clearly states that a marriage is legal if it is carried out according to the law of each religion and belief. Couples who have different religions must determine whose religion they will choose to marry. The next question is whether this religion justifies interfaith marriage. In Islam, the prohibition on interfaith marriages can be found in the Qur'an Surah Al-Baqarah verse 221 which translates "do not marry polytheist women before they believe. This verse obviously contains an element of prohibition "don't" or shouldn't. The verse is continued with the statement "and do not marry an idolatrous male with a woman who believes before the idolatrously male believes. The rules that have been written in the holy book were revealed so that people would take lessons.

Other religions in Indonesia also prohibit interfaith marriage. Christianity forbids interfaith marriage. East Bandung Batak Christian Protestant Pastor (HKBP), Jerry TP Aruan, expressly disagrees with interfaith marriages. According to Jerry, there are two conditions for a marriage at the HKBP Church, namely having been baptized and having been on subsidization or going through the catechism process. People who have been on the side already know the teachings of Christianity thoroughly. Therefore, it is impossible for interfaith marriages to occur. This prohibition is not only related to the pastor who blesses, but also with the acceptance of the people towards the marriage[12]

The next issue relates to the registration of marriages. Article 2 paragraph (2) of the Marriage Law stipulates that every marriage must be registered according to the prevailing laws and regulations. Provisions regarding the registration of marriage can be found in Article 2 of Government Regulation Number 9 of 1975 which states that for couples who are Muslim, registration is carried out by a registrar employee as referred to in Law Number 32 of 1954 concerning the registration of marriage, divorce, and reconciliation. Meanwhile, the registration of marriages made by people who have a religion other than Islam, the registration will be carried out by a marriage registrar at the Civil Registry Office. In this government regulation, it does not mention the registration of those who are married to different religions. In Indonesia, there are only a few cities whose Civil Registry Offices are willing to record religious differences, those are Yogyakarta, Surabaya, Bali, and Salatiga on the condition that one of the couples resides in the jurisdiction where the recording of different religions will be carried out. The registration of marriage will have an impact on the status of the child born in that marriage. Article 42 of the Marriage Law states that "A legal child is a child born in or how can the position of a child be said to be valid if the registration of the marriage of the parents alone cannot be done because of questionable legality. By law, the absence of registration results in the absence of protection for the child born from the marriage.

Some argue that recording is not in the context of the legality of marriage, but only in administrative reporting.[13] To overcome the legal vacuum regarding marriage registration, the law Population Administration, namely Law No. 23 of 2006 as amended by Law No. 24 of 12013 concerning Amendments to Law No. 23 concerning Population Administration provides opportunities for couples who will carry out interfaith marriage to record the marriage. Article 35 letter a of the Law states that marriage registration regulated in Article 34 of the Adminduk Law also applies to marriages 
determined by the court. Elucidation of Article 35 letter a of the Adminduk Law provides an explanation that a marriage determined by the court is a marriage between a couple of different religions.

\subsection{Actions Taken by Couples Who Have Married Different Religions Related to the Implementation of Their Marriage}

During the Dutch rule, interfaith marriage was included in the notion of mixed marriages. The Dutch East Indies government at that time issued the King's Decree on December 29, 1896, No. (Stb. 1898 No. 158) which is a regulation on Mixed Marriages (Regeling op de Gemengde Huwelijken), hereinafter written GHR. Article 1 GHR states that what is meant by mixed marriages is marriages between people in Indonesia who are subject to different laws. Lawyers argue that what constitutes a mixed marriage is a marriage between a man and a woman who are each subject to different laws. In Article 7 paragraph (2) of GHR it is stated that in this mixed marriage, differences in religion, race, or origin do not in any way constitute a marriage. Based on the exposure, the marriage of different religions before the enactment of the marriage law, including in mixed marriages regulated in the GHR, and its implementation is recorded in the Office of Civil Records. After the existence of the Law of Marriage is valid / the absence of marriage is very much determined by the religious law and beliefs of each prospective bride. This situation is clear in Article 2 of the Marriage Law that "Marriage is valid if it is done according to their respective religions and beliefs." In the explanation of Article 2 paragraph (1), it is stated that there is no marriage outside his religious law and belief. Hazairin, explicitly and clearly gives the interpretation of article 2 that for Muslims there is no possibility to marry by violating the law of their own religion. [14] The same is true for Christians, and for Hindus. Therefore, it means a dead end for prospective brides of different religions to perform interfaith marriages. Because, in addition to the rules in this Article 2, they are also unlikely to use mixed marriage rules in Chapter XII article 57 of the Marriage Law, which does not regulate interfaith marriage. Article 66 of the Marriage Law states that with the enactment of this Law the provisions set out in the Book of Civil Law (Burgerlijk Wetboek), Christian Indonesian Marriage Ordinance (Huwelijk Ordonantie Christen Indonesiers, S. 1933 No. 74), Mixed Marriage Regulations (Regeling op de Gemengde
Huwelijkinvalid S. 158 of 1898) and other regulations governing marriage to the extent that it has been regulated in this Act, are declared. From the provisions of Article 66, it can be stated that the provisions of interfaith marriage in GHR no longer apply, while mixed marriages in the Marriage Act have different formulations.

Regarding Article 66, there are some lawyers who say that there is a legal void regarding the intermarriage of different religions. Because the Marriage Law does not regulate marriages of mixed religions, while the sound of Article 66 states that the old marriage rules do not apply as long as they have been regulated by the Marriage Law.[15] It is stated by several scholars including Purwanto S. Ganda Subrata that mixed marriages between religions as long as it is not directly regulated in the Marriage Law can be carried out in accordance with the provisions of GHR in accordance with the principles in the Marriage Law.[16] Maria Ulfa Subadio also stated that although the marriages of Indonesians of different religions are not regulated in the Marriage Act, under Article 66, the provisions in the GHR can still be used in interreligious marriages.[17] The absence of provisions on interfaith marriage in the Marriage Law also raises uncertainty about the provisions of the law as a guide in its implementation. To overcome legal and administrative barriers, couples of different religions usually use a variety of strategies in order to hold their marriage despite religious differences. According to Harkristuti, these methods are actually done to avoid the law, some of the ways taken by couples of different religions are:

\section{a. Transfer of Religion}

One of the most common methods involves one of a couple who converts, or pretends to convert, for example, one of them will declare a creed to convert to Islam, or whatever the religious conditions of his partner, although some are always true switching religions to the religion embraced by his partner. However, there are also those who after marriage remain with their own religion and beliefs, as Eva Dewi did. In 2009, Eva Dewi converted to Islam to marry her lover at the time. Eva who grew up as a Christian read the creed and became a Muslim on paper, according to Eva Dewi, She just thought it was the least complicated way. The mother, who now has three children, admitted that her religion changed from Christian to Islamic with a new ID card, so that she could get married at KUA. However, deep down, Dewi has not yet become a Muslim. Sometimes the Goddess still 
goes to church. An incident that is very similar to the story of Aya a Catholic with a Muslim husband. They decided to get married Catholic. The main reason is that the Catholic Church recognizes interfaith marriage. That means there is no Sacrament of Marriage for them.[18] Marrying a Catholic is a practical reason for them because in terms of administration he says there are no significant obstacles and there is no problem if her husband still believes his religion again[19]

\section{b. Getting Married Abroad}

Couples of different religions often choose to get married abroad. Popular places for interfaith weddings such as Hong Kong, Australia, and Singapore. Ni Luh Putu Ayumi Yuttari Putri, a Balinese Hindu convert who married a Muslim, chose to marry in Singapore because marrying different religions in Indonesia is not an easy thing[20]

\section{c. Getting Married According to Their Own Religion}

To their respective religions, Muslim and Christian couples perform marriage vows as well as blessings. Even if the Muslim-Christian couple is Protestant, the procession can be held in the same place, either at home or in the Building. If Catholic, the blessing must be performed in the Church, then for the marriage contract to be performed afterwards, it can be on the same day or a different day[21]. The implementation of this kind of marriage is due to the understanding that in the Marriage Law there is no prohibition on a marriage of different religions, there is only regulated the matter of how the marriage is carried out, that is, it must be in accordance with their respective religious laws.

\section{d. Requesting a Court}

Settlement A court order is a court decision on a matter of application (voluntary) on interfaith marriage. This method was taken by Boy Bolang and Aditya as waiting for a marriage permit from the West Jakarta State Name, Jamal Mirdad is a Muslim couple and Lidia Kandau is a Protestant Christian. who postponed his marriage for two months due to waiting for the court process but finally got a permit from the DKI Jakarta Civil Registry Office. Another case occurred in the couple Andy Vonny Gani P. who is a Muslim with Adrianus Petrus Hendrik Nelwan who is a Protestant. They came to KUA Tanah Abang Jakarta, applied for their marriage to be held according to Islam, but KUA refused the request due to religious differences. Then the two faced the Civil Registry Office, but the Civil Registry Office also refused. Because KUA and the Civil Registry Office refused to hold their marriage, they finally applied to the Central Jakarta District Court[22] which eventually ordered the Civil Registry Office to hold and record their marriage.

\section{CONCLUSION}

1) Indonesia's positive legal provisions do not explicitly prohibit interfaith marriages. However, from the existing provisions and the position of Indonesia as a non-secular country, it is interpreted that in Indonesia, marriages of different religions cannot be held.

2) Married religious couples usually get pressure from their families, relatives, and religious leaders, as well as difficult bureaucratic requirements. To overcome this obstacle, couples of different religions usually use various means so that they can have a marriage.

3) Article 35 of Law No. 23 of 2006 on Population Administration as amended by Law No. 24 of 2013 on Amendments to Law No. 23 of 2006 on Population Administration only regulates the legality of administration or registration of marriages of different religions but does not regulate the legality of interfaith marriage as referred to in Article 2 paragraph (1) of the Marriage Law.

\section{REFERENCES}

[1] Hilman Hadikusuma, Indonesian Marriage Law According to Adat Law, Religious Law, 2nd print. Bandung: Mandar Maju, 2003.

[2] Rachmadi Usman, "The Meaning of Marriage Registration in Indonesian MarriageLegislation," Indones. Legis., vol. 14, no. Mariage Legislation, p. 260, 2017.

[3] Rachmadi Usman, "The Meaning of Marriage Registration in Indonesian MarriageLegislation," Indones. Legis., vol. 14, no. Mariage legislation, p. 260, 2017.

[4] Sri Wahyuni, "Marriage of Different Religions in Indonesia and Human Rights," Ejournal, p. 132, 2016.

[5] Kompas, "Mariage in Different Religion," Kompas.com, p. 1, Nov. 23, 2019. 
[6] Kompas, "Mariage in Different Religions," Kompas.com, p. 1, Nov. 23, 2019.

[7] Kompas, "Menag Apresiasi MK soal Pernikahan Beda Agama," Kompas.com, p. 1, Jun. 22, 2015.

[8] National Legal Development Agency (BPHN), Legal Studies on Marriages of Different Religions (Comparison of Several Countries). Jakarta: Ministry of Law and Human Rights, 2011.

[9] F. Agustin, "Position of Children in Marriage with Different Religions," Leg. Stud., vol. 2, p. 133, 2018.

[10] Bimo Walgito, Guidance for Counseling in Marriage. Yogyakarta, 2004.

[11] Insertlive, "Orang Tua Beda Agama, dr Tirta Sempat Ateis Sebelum Mualaf," Insertlive.com, p. 1, Oct. 16, 2020.

[12] Hukum Online, "Ini Pandangan Pendeta HKBP Seputar Nikah Beda Agama," Hukum Online.com, p. 1, Sep. 25, 2014.

[13] Ibtimes, "Perkawinan Beda Agama, Apa Dampaknya?.," Ibtimes.id, p. 1, Apr. 12, 2020.

[14] Hazairin, Democracy Pancasila. Jakarta: Bina Aksara, 1983.

[15] Djaya S. Melida, Problems of Interfaith Marriage and Belief in Indonesia in a Legal Perspective. Jakarta: Vrana Widya Darma, 1988.

[16] Djaya S. Melida, The Problem of Intercultural Marriage in Indonesia in a Legal Perspective. Jakarta: Vrana Widya Darma, 1988.

[17] Maria Ulfa Subadio, The Struggle to Achieve the Marriage. Jakarta: Idaya, 1981.

[18] Nasution Usman Adji, Running and InterReligious Marriage. Yogyakarta: Liberty, 1989.

[19] katolikana, "Dispensasi Gereja Katolik dalam Perkawinan Beda Agama," Katolikana wajah gereja Nunsantara, p. 1, Jun. 08, 2020.

[20] Bridestory, "Pasangan Suami-Istri Berbagi Tips dan Pengalaman Menikah Beda Agama," Bridestory, p. 1, Jan. 24, 2020.

[21] Hops.id, "Bisakah nikah beda agama di Indonesia? Ternyata bisa, ada triknya," Hops.id, p. 1, Aug. 2020.
[22] Sri Wahyuni, "Marriage of Religious Differences in Indonesia and Human Rights," Ejournal, 2016, [Online]. Available: ejournal. uin.suka.ac.id. 